\title{
Hydrogeological conditions in the southern part of Dang valley, mid-western Nepal
}

\author{
Birendra Sapkota* \\ AmritCampus, Kathmandu, Nepal \\ * For correspondence, E-mail: birendrasapkota@hotmail.com
}

The Dang valley consists of several patches of confined and unconfined aquifer systems. Drilling data reveals that the northern portion of the study area has more permeable surfaces than the southern and central portions. Annual domestic draft and safe yield were calculated to be $7.43 \times 10^{6} \mathrm{~m}^{3} /$ year and $3.16 \times 10^{7} \mathrm{~m}^{3} /$ year, respectively. The fact that the safe yield is higher than the annual draft indicates the presence of good groundwater potential in the study area.

Key words: terrace, lithology, aquifer, tubewell, yield, draft, piezometric surface, water table

Him J Sci 1(2): 119-122

URL: www.himjsci.com/issue2/ hydrogeology
Received: 27 Apr 2003

Accepted after revision: 15 July 2003

\section{Introduction}

Bounded on three sides by the Siwaliks, the Dang valley is approximately $80 \mathrm{~km}$ in length and $30 \mathrm{~km}$ in width and thusits area is approximately $2400 \mathrm{~km}^{2}$. Theelevation of the valley floor ranges from 550 to $750 \mathrm{~m}$ asl. The study area stretches from below the Ghorahi-Tulsipur highway in the north down to the Babai River in the south, from Ghorahi in the east to Tulsipur in the west (Figure 1).

TheDangvalleyhasan undulatingterrain sloping towards south. The terrain, consisting mainly of alluvium and outwash deposits from the hill slopes, comprises six terraces- the highest terrace, higher terrace, middle terrace, lower first terrace, lower second terrace and lower third terrace (Yamanaka and Yagi 1984). These are fill-top terraces composed of consolidated detritus. The valley is filled in the central part with fluviolacustrine sediments. Ancient river terraces are more prominent in the northern part of the valley than in the south. The fluvial terraces include soils of diverse types in different regions. Red soil is observed in the northern area, brown in the middle and black in the south and eastern parts of the valley.

The Babai River is one of the major rivers in the Dang valley, flowing east to west and passing through the southern end of the valley. Other perennial streams, such as the Sisne and the Katwa, originatein thelesser Himalaya and join theBabai River on the south, creating alluvial fan plains, sand and gravel bars, depositional basinsand other depositional landforms. Theerosional activity of the rivers has indented the river terrace of the valley by 8 to $15 \mathrm{~m}$ and has created badland topography in the northern part.

Climate in the Dang valley is tropical to sub-tropical, characterized bymonsoon rainfallsfrom Juneto September, which on average account for $85 \%$ of thetotal annual rainfall (Uprety and Karanjac 1989).

\section{Study area}

The subsurface lithology obtained from boreholelogs of deep tubewells (DTWs) and shallow tubewells (STWs) consists primarilyof sand, gravel, siltand clay, mixed in differing proportions. The comparativestudy of these wells shows that thenorthern part of the valley has more sand and gravel. Towards the south and especially along the Babai River, clay and silt are dominant. Intermixing of gravel and fines is dominant in the middle part of the study area.

\section{Materials and methods}

A field survey was undertaken to determine the hydrogeological conditionsin thestudy area, and the preliminary data was collected at the Groundwater Resource Development Board (GWRDB), Kathmandu and Groundwater Field Office, Lamahi.

Various types of wells (dugwells, deep tubewells and shallow tubewells) selected for present study were located in a location map (Figure 1). The study was conducted in June 1999 (during the monsoon) and February 2000 (post-monsoon). The depth of water from the ground surface in the dugwells both in monsoon and post monsoon was noted. Geological information regarding the dugwell section of the fluvial terrace was correlated with the nearest columnar section but data from shallow tubewells and deep tubewells was obtained from borehole logs.

Transmissivity was calculated using figures for well discharge obtained from secondary data. Water table measurements taken from dugwells of study area were useful in determining the direction of groundwater flow.

Safe yield of the groundwater reservoir was calculated for the entire aquifer system based on the piezometric surface fluctuation. Thiswas relevantsincetheclay zonesoccur asisolated patches in most of the areas, with laterally interconnected deep and shallow aquifers. Thus, safeyield can becal culated on thebasis of the following formula:

Safe yield $=$ area of aquifer $\times$ storage coefficient $\times$ mean piezometric surface fluctuation (cf. Driscoll 1987)

Typical storage coefficient for confined aquifers ranges from $10^{-5}$ to $10^{-3}$ (Driscoll 1987). The above parameters showed the potential of groundwater in the valley and the possibility of future well development for irrigation and drinking water purpose. 


\section{Results and discussion}

Aquifer setting

The general pattern of aquifers, as revealed from the lithological logs, isirregular and discontinuouswith lenses or layers of sediment admixture at different levels. Unconfined aquifers are observed in Dhikpur and Dangigaun. Confined ones are commonly observed at Bangain, Dhikpur and in many other places. The presence of confined aquifers may be due to the shifting of the river course within thevalley.

Asfar asshallowtubewellsin thestudyareaareconcerned, the best granular zoneisfound in the well of Ammapur (DG/STW7), which has a total of $14.6 \mathrm{~m}$ thick permeable material (sand and gravel) out of the total well depth of $20.1 \mathrm{~m}$ (Table 1).

As for deep tubewells, the thickness of permeable materials varies from $18.5 \mathrm{~m}$ in TG-2 (Bangain) to $84.7 \mathrm{~m}$ in DG/ DTW-5(Dhikpur). Thethickest clay zone, 49.3 m appearsin NISP/ INV/ DTW-3 (Khausapur) (Table 2). Most lithologs of the wells reveal the permeable material to be greater than $40 \%$, indicating good presence of aquifers in the valley (Table 1 and 2 ).

Piezometric surface

The piezometric surfacein deep tubewellsasrecorded by GWRDB ranges from $5.1 \mathrm{~m}$ in DG/DTW-27 (Dangigaun) to $37.5 \mathrm{~m}$ in DG/ DTW-21 (Lalpur), and in shallow tubewells ranges from $0.7 \mathrm{~m}$ in NISP/STW-7 (Ammapur) to 5.0 m in DG/STW-6 (Dundre) (Table 4). Thegeneral pattern observed in thearea is an increasein depth to piezometric surface towards the northern part of the valley.

Water table

The greater fluctuation of water level, as revealed by the dugwell inventory data, takes place in central and northern parts of the valley (Table3). The depth to water level in dugwells is found to be less toward the south and near the banks of river. This may be due to high transmissivity in wells toward the north, resulting in rapid recharge of storage during the monsoon season and quick release of water to the south during post-monsoon (Uprety and Karanjac 1989).

Yield

The maximum yield is greater in the central and southern part of the area, in places such as Dundre (DG/STW-6) and Dangigaun (DG/DTW-27) (Table4). Thissuggeststhat thesouthern and central parts of thestudy area would offer better venuesin which to develop tubewells for irrigation purposes.

\section{Transmissivity}

Transmissivity in the deep tubewells of Dangigaun (DG/DTW-27) and Ammapur (DG/STW-7) is greater than in other wells of the valley. Hydraulic conductivity, calculated as the ratio of transmissivity to cumulative aquifer thickness, is also greater in these wells. Even wells adjacent to each other, for example NISP/ STW-7andDG/STW-7mayvaryin transmissivity. Thediscontinuous

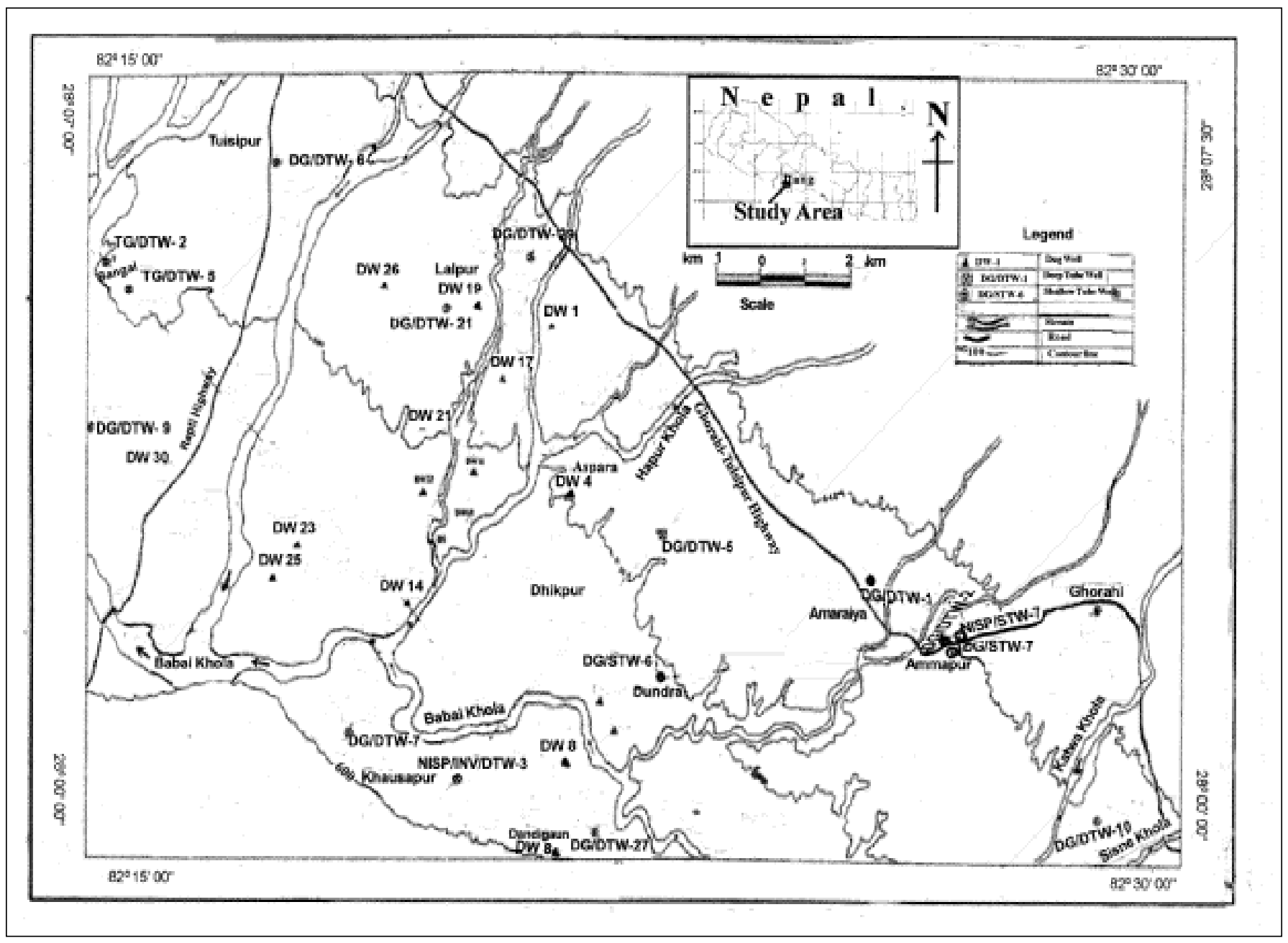

FIGURE 1. Location map of the study area 
TABLE 1. Thickness of permeable, semi-permeable and impermeable layers in STWs

\begin{tabular}{|c|c|c|c|c|c|c|}
\hline \multirow[t]{2}{*}{ WellNo. } & \multirow[t]{2}{*}{ Location } & \multirow{2}{*}{$\begin{array}{l}\text { Depth } \\
\text { ofwell } \\
\text { drilled* } \\
\text { (m) }\end{array}$} & \multicolumn{3}{|c|}{ Thickness of (m) } & \multirow{2}{*}{$\begin{array}{l}\text { \%of } \\
\text { permeable } \\
\text { materials }\end{array}$} \\
\hline & & & $\begin{array}{l}\text { Permeable } \\
\text { layer }\end{array}$ & $\begin{array}{l}\text { Impermeable } \\
\text { layer }\end{array}$ & $\begin{array}{l}\text { Semi } \\
\text { permeable } \\
\text { layer }\end{array}$ & \\
\hline DG/STW-6 & Dundre & 37.5 & 18.3 & 9.4 & 9.7 & 48.8 \\
\hline Saibahani & Ghorahi & 29.0 & 15.5 & 8.0 & 5.6 & 53.4 \\
\hline NISP/INV/STW-7 & Ammapur & 36.0 & 13.0 & 22.0 & 1.0 & 36.1 \\
\hline DG/STW-7 & Ammapur & 20.1 & 14.6 & 4.6 & 0.9 & 72.8 \\
\hline
\end{tabular}

TABLE 2. Thickness of permeable, semi-permeable and impermeable layers in DTWs

\begin{tabular}{llllll}
\hline Well No. & $\begin{array}{l}\text { Depth } \\
\text { ofwell } \\
\text { drilled* } \\
\text { (m) }\end{array}$ & $\begin{array}{l}\text { Perme } \\
\text { ablelayer }\end{array}$ & $\begin{array}{l}\text { Thperme } \\
\text { ablelayer }\end{array}$ & $\begin{array}{l}\text { Semi- } \\
\text { permeable } \\
\text { layer }\end{array}$ & $\begin{array}{l}\text { \%of } \\
\text { permeable } \\
\text { materials }\end{array}$ \\
\hline DG/DTW-2 & 68.9 & 41.4 & 11.9 & 15.6 & 60.1 \\
NISP/INV/DTW-3 & 106.1 & 45.5 & 49.3 & 11.2 & 42.6 \\
DG/DTW-27 & 111.2 & 58.2 & 41.0 & 12.0 & 52.3 \\
TG-5 & 107.0 & 49.0 & 6.5 & 52.0 & 45.8 \\
TG-2 & 105.0 & 18.5 & 7.0 & 79.5 & 17.6 \\
DG/DTW-29 & 113.5 & 63.5 & 29.5 & 20.5 & 55.9 \\
DG/DTW-5 & 140.2 & 84.7 & 43.9 & 11.6 & 60.4 \\
DG/DTW-7 & 111.2 & 76.0 & 18.0 & 17.2 & 67.7 \\
DG/DTW-9 & 80.2 & 38.7 & 27.1 & 14.3 & 48.3 \\
DG/DTW-6 & 70.1 & 54.9 & - & 15.2 & 78.2 \\
DG/DTW-1 & 149.3 & 64.6 & - & 71.3 & 43.3 \\
DG/DTW-21 & 74.4 & 49.9 & 18.9 & 5.6 & 67.1 \\
\hline
\end{tabular}

TABLE 3. Dugwell inventory preparation data of study area

\begin{tabular}{llllll}
\hline Well No. & Location & $\begin{array}{l}\text { Well } \\
\text { depth } \\
\text { (m bgl) }\end{array}$ & $\begin{array}{l}\text { Postmonsoon } \\
\text { water level } \\
\text { depth (masl) }\end{array}$ & $\begin{array}{l}\text { Monsoon water } \\
\text { level depth } \\
\text { (mas) }\end{array}$ & $\begin{array}{l}\text { Water level } \\
\text { fluctuation } \\
\text { (m) }\end{array}$ \\
\hline DW1 & Mangari & 16.0 & 612.7 & 513.2 & 0.5 \\
DW4 & Aspara & 6.0 & 592.4 & 596.0 & 3.6 \\
DW8 & Dhikpur & 6.0 & 585.3 & 587.8 & 2.5 \\
DW9 & Dangigaun & 10.0 & 583.4 & 587.5 & 3.5 \\
DW 10 & Duruwa & 10.0 & 581.0 & 584.0 & 3.0 \\
DW14 & Duruwa & 9.0 & 582.7 & 586.9 & 4.2 \\
DW15 & Manoharpur & 10.0 & 582.6 & 584.8 & 2.2 \\
DW17 & Bankatta & 8.0 & 610.7 & 613.9 & 3.2 \\
DW 19 & Lalpur & 8.0 & 619.5 & 621.9 & 2.4 \\
DW21 & Bhituria & 13.0 & 593.6 & 594.2 & 0.6 \\
DW23 & Malawar & 7.0 & 581.6 & 584.5 & 2.9 \\
DW25 & Karanga & 9.0 & 569.4 & 573.9 & 5.5 \\
DW26 & Sajnewar & 8.0 & 607.6 & 608.5 & 0.9 \\
DW 30 & Hemnagar & 7.0 & 581.8 & 584.9 & 2.7 \\
\hline
\end{tabular}

Source: GWRDB (1996); $m$ bgl: meters bel ow ground level, $m$ asl: meters above sea clay layers present in the aquifer differ in percentage of the permeable material. Thus, wells with more cumulative thickness of the aquifer tapped zone give moretransmissivity.

\section{Groundwater recharge}

In the study area, the aquifers are mainly recharged by rainwater infiltration. In addition, parallel streams flowing across the valley assist in recharging the valley. Since the northern fringe of the valley consists of coarse materials (gravels and boulders), major recharge occurs in this zone.

\section{Safe yield}

The storage co-efficient is much lower in confined aquifers because they are not drained during pumping. Any water released fromstorageisobtained primarily by compression of the aquifer and expansion of the water when pumped. Thus, assuming the higher value for the aquifer in the study area, which is $10^{-3}$ (Driscoll 1987),

Safe yield $=$ area of aquifer $\times$ storage coefficient $\times$ mean piezometric surface fluctuation

$$
\begin{aligned}
= & \sim 24 \times 10^{8} \mathrm{~m}^{2} \times 10^{-3} \times 13.2 \mathrm{~m} / \\
& \text { year* } \\
= & \sim 3.16 \times 10^{7} \mathrm{~m}^{3} / \text { year }
\end{aligned}
$$

*mean piezometric surface fluctuation $=13.2 \mathrm{~m} /$ year (Piya 1993)

Groundwater draft

In the valley groundwater is extracted through dugwells, deep tubewells and shallow tubewells. The requirement for drinkingand domestic use per person per day as per WHO (1984) standard is 45 I $\left(0.045 \mathrm{~m}^{3}\right)$. The estimated population of Dangvalleyin 1995 was 411149(CBS1996). Therefore the total amount of groundwater draft by that population is $411,149 \times 45 \mathrm{l} /$ day $=18,501,705 \mathrm{l} /$ day.

For livestock, total draft of groundwater as estimated byWHO (1984) is $1 / 10$ of population demand. Thisisequal to $1,850,171 \mathrm{l} /$ day. Total groundwater draft for domestic purposes comes to be $20351876 \mathrm{l} /$ day, or $7.43 \times 10^{6} \mathrm{~m}^{3} /$ year. This is about $48.7 \%$ of the groundwater storage.

Thus, the annual draft for domestic use is less than safe yield, or in other words, the recharge rate is much higher than the draft. Therefore, with proper planning and management, extensivewell development can becarried out in the valley in the future. However, irrigation of maximum land surface can 


\section{RESEARCH PAPERS}

TABLE 4. Hydrogeological characteristics of deep and shallow aquifers

\begin{tabular}{|c|c|c|c|c|c|c|c|}
\hline Well No. & $\begin{array}{l}\text { Water } \\
\text { level } \\
\text { (masl) }\end{array}$ & $\begin{array}{l}\text { Depth of } \\
\text { well } \\
\text { (m) }\end{array}$ & $\begin{array}{l}\text { Total cumulative } \\
\text { thicknessof } \\
\text { aquifer (m) }\end{array}$ & $\begin{array}{l}\text { Piezometric } \\
\text { surface } \\
\text { (m bgl) }\end{array}$ & $\begin{array}{l}\text { Discharge/ } \\
\text { maximum yield } \\
\text { (m²/day) }\end{array}$ & $\begin{array}{l}\text { Transmissivity } \\
\text { (m²/day) }\end{array}$ & $\begin{array}{l}\text { Hydraulic } \\
\text { conductivity } \\
\text { (m/day) }\end{array}$ \\
\hline DG/DTW-6 & 632.0 & 70.1 & 9.18 & 15.8 & 1483.5 & 3394.0 & 369.7 \\
\hline TG-5 & 608.0 & 107.0 & 30.0 & 21.0 & 691.2 & 632.5 & 21.1 \\
\hline DG/DTW-9 & 633.0 & 113.5 & 37.2 & 6.0 & - & - & - \\
\hline DG/DTW-21 & 618.0 & 74.4 & 16.5 & 37.5 & - & - & - \\
\hline DG/DTW-7 & 580.0 & 111.2 & 21.4 & - & 630.0 & - & - \\
\hline DG/DTW-3 & 583.0 & 106.1 & - & 11.0 & - & - & - \\
\hline DG/STW-7 & 638.0 & 20.1 & 7.1 & 3.2 & 950.4 & 3477.5 & - \\
\hline DG/DTW-5 & 610.0 & 140.0 & 22.0 & 9.2 & 167.1 & 101.9 & 4.6 \\
\hline NISP/STW-7 & 636.0 & 36.0 & 6.1 & 0.7 & 661.8 & 712.5 & 117.3 \\
\hline DG/STW-6 & 580.0 & 37.5 & 6.1 & 5.0 & 1987.2 & - & - \\
\hline DG/DTW-27 & 586.0 & 111.2 & 33.9 & 5.1 & 2592.0 & 3953.0 & 116.4 \\
\hline DG/DTW-1 & 619.0 & 149.4 & 11.0 & 15.2 & 194.4 & 14.2 & 1.3 \\
\hline DG/DTW-2 & 641.0 & 68.9 & 11.1 & 23.7 & - & - & - \\
\hline Saibahini & 666.0 & 29.0 & - & - & 0.1 & - & - \\
\hline TG-2 & 604.0 & 105.0 & 30.4 & 28.9 & 1036.2 & 2709.3 & 89.1 \\
\hline
\end{tabular}

Source: GWRDB (1996); $\mathrm{m}$ asl : meters above sea level; $\mathrm{m}$ bgl: meters bel ow ground level

be achieved through combined use of both the surface water and groundwater.

\section{References}

CBS. 1996. Statistical pocket book. Kathmandu: Central Bureau of Stastics, HMGN. $301 p$

Driscoll FG. 1987. Groundwater and wells, 2nd ed. St. Paul (Minnesota): Johnson Filtration System Inc. 5512. 1089p

GWRDB. 1996. A compilation of tube-well inventorydata of Dangvalley,mid-western Nepal. Kathmandu:Groundwater ResourceDevelopmentBoard. 52p

Piya B. 1993. Hydrogeological studies in parts of Dang valley, western Nepal [thesis]. Kathmandu: Central Department of Geology, Tribhuvan University. 120p
Uprety SR and J Karanjac. 1989. Shallow well drilling, testingand monitoringin 1987/ 88: Basic documentation and preliminaryinterpretation, Dangvalley.Technical reportno 8. Kathmandu:UNDP and HMGN. 19+38p

WHO. 1984. Guidelines for drinking water quality, Vol 1. Geneva: World Health Organization

YamanakaH and HYagi. 1984. Geomorphological development of theDangdun.J Nep Geol Soc 4: 151-9

\section{Acknowledgements}

I amgrateful to Megh RDhital, Central DepartmentofGeology,TU, for supervising thisstudy, and to MadhavBelbase, GWRDB, Lamahi, for providingmaterialsand allowingthefield observation of therunningtubewells. 